\title{
Inhibition of Heterocyclic Aromatic Amines in Pork Chops Using Complex Marinades with Natural Antioxidants
}

\author{
Margit D. Aaslyng*, Birgitte Winther Lund, Kirsten Jensen \\ Danish Meat Research Institute, Technological Institute, Department of Meat Technology, Taastrup, Denmark \\ Email: *mdag@teknologisk.dk
}

How to cite this paper: Aaslyng, M.D., Lund, B.W. and Jensen, K. (2016) Inhibition of Heterocyclic Aromatic Amines in Pork Chops Using Complex Marinades with Natural Antioxidants. Food and Nutrition Sciences, 7, 1315-1329.

http://dx.doi.org/10.4236/fns.2016.714120

Received: July 28, 2016

Accepted: December 2, 2016

Published: December 5, 2016

Copyright $\odot 2016$ by authors and Scientific Research Publishing Inc. This work is licensed under the Creative Commons Attribution International License (CC BY 4.0).

http://creativecommons.org/licenses/by/4.0/ (c) (i) Open Access

\begin{abstract}
Five marinades were developed using natural antioxidants. Based on a consumer test of the appearance, three marinades were chosen for further investigation: an oregano, an acerola and a Dijon marinade, the Dijon marinade containing acerola, sumac and oregano. A barbecue and a sumac marinade were not included in the further study. In a home use test, consumers barbecued pork chops with the three marinades. Most of the consumers preferred the oregano and the Dijon marinade, while the acerola marinade was less liked. After controlled cooking using both direct and indirect heat to a core temperature of $65^{\circ} \mathrm{C}$ and $80^{\circ} \mathrm{C}$, the content of the heterocyclic aromatic amines (HCA) PhiP, MeIQx, DiMeIQx, Harman and Norharman was analysed. All of the marinades reduced the content of MeIQx and DiMeIQx, although only with indirect heat, while PhiP was reduced using both grilling methods. Surprisingly, in particular the content of Harman-and to a lesser extent Norhaman-was very high in the Dijon-marinated chops. The results demonstrated that it was possible to develop well-liked marinades that can reduce the formation of selected HCAs.
\end{abstract}

\section{Keywords}

Pork, Marinades, Heterocyclic Aromatic Amines

\section{Introduction}

When meat is heated, potentially harmful compounds (heterocyclic aromatic amines (HCA)) can be formed. Two pathways exist: a Maillard-like reaction involving creatine at temperatures ranging between $160^{\circ} \mathrm{C}$ and $250^{\circ} \mathrm{C}$ [1] and a pyrolysis of amino acids if the temperature exceeds approximately $250^{\circ} \mathrm{C}$ [2]. The formation and carcinogenicity of these compounds and the influence of the cooking parameters have previously been 
reviewed by Sanz-Alaejos \& Afonso [2], who showed that the compounds can be formed in all meat types and that their formation especially depends on a combination of time and level of heat exposure.

HCAs have been proposed as one of the mechanisms behind the observed association between meat intake and colorectal cancer [3]. In particular, the three HCAs MeIQx (2-amino-3,8-dimethylimidazool[4,5- $f$ ]quinoxaline), diMeIQx (2-amino-3,4,8-trimethylimidazool[4,5- $f$ quinoxaline) and PhiP (2-amino-1-methyl-6-phenylimidazo[4,5b]pyridine) have shown an association with the incidence of colorectal cancer in an epidemiological study. It is important to bear in mind that the risk of cancer is complex and does not relate to meat intake alone, but rather to the whole diet, including the intake of fruit and vegetables [4]. Besides diet, it also includes general lifestyle habits [5] and genetic make-up [6]. Nevertheless, it is recommended to reduce the intake of HCAs.

The formation of HCAs is a redox reaction, and antioxidants have the potential to reduce the formation of the HCAs. Several studies have shown that natural antioxidants in the form of spices, berries, wine or beer can reduce the formation of HCAs in beef [7] [8] [9], pork [10] [11] and chicken [12] [13]. As previous research has demonstrated, pork chops, in particular, are often marinated before barbecuing [14], and there exists the potential to produce marinades using antioxidant herbs and berries, thus reducing the risk of formation of HCAs during barbecuing.

Most of the studies investigating different natural antioxidants have used either a pure spice or berries or an extract of these in the experiments [9] [11]. However, in gastronomy, these taste-givers are mainly added to commercial marinades that also include other ingredients, and the impact of this more complex matrix has not been investigated. Furthermore, numerous investigations have focused on the ability of the active compound to reduce HCAs and have overlooked the sensory quality of the marinated meat [13] [15] [16]. However, it seems important to combine the chemical analysis of the effect of the compounds with a sensory and consumer study to evaluate the gastronomic value.

The aim of this investigation was to evaluate the effect of palatable complex marinades based on acerola, oregano and sumac on the inhibition of the formation of heterocyclic amines and to relate the marinades to the consumer responses.

In our study, we focused on marinades based on one herb (oregano) and two berries (acerola and sumac). Oregano (oregano vulgare) has high antioxidant capacities because of its content of polyphenols, flavonoids and different compounds in the essential oil such as carvacrol, thymol, $\gamma$-terpinene and linalool [17] [18]. Oregano has previously demonstrated its potential in increasing the shelf life of meat by reducing lipid oxidation [19]. However, it has only scarcely been investigated with respect to the reduction of HCA formation, and the results from a model study show divergent results depending on the treatment [20]. The acerola berry (Malpighia emarginata) has strong antioxidant properties [21] because of its high content of ascorbic acid [22] and phenolic compounds [23]. Acerola is capable of increasing the shelf life of beef patties by reducing oxidation [24] but has not yet been used to inhibit the formation of HCAs. The su- 
mac berry (rhuscoriaria) is widely used in the Mediterranean region. Over 180 phenolic and other phyto-constituents have been identified in sumac [25], and water extract, in particular, has been shown to have strong antioxidant properties. However, as with acerola, its effect on the formation of HCAs has yet to be explored. The antioxidativity of all three compounds was initially analysed in water extracts to ensure its presents, by an oxygen micro sensor (Clark electrode, micro-respiration system, Unisense, Denmark) and a DPPH radical scavenging assay. However, it was not possible to get reliable analytical results of antioxidativity in the finished marinades, as the complex recipes caused unstable measurements.

\section{Material and Methods}

\subsection{Food Ingredients-Marinades and Meat}

The common ingredients of the marinades were purchased at a local grocer. Frozen acerola puree (Bloch \& Schou Aps, Viborg, Denmark) was freeze-dried before use. Oregano and sumac (ENES Gewürze $\mathrm{GmbH}$, Geesthacht, Germany) were used dried as they were bought. The acerola and oregano marinade was an oil/water emulsion $(\mathrm{O} / \mathrm{W})$. The Dijon marinade and sumac marinade was oil based while the barbecue marinade was water-based. The ingredients are given in Table 1. Danish cold pressed rapeseed oil (Lehnsgaard, Aakirkeby, Denmark) was used as the base of the marinades.

Boneless pork loins ( $\mathrm{m}$. longissimus dorsi) with approximately $3 \mathrm{~mm}$ fat rim, purchased from a commercial Danish slaughterhouse, were used for all experiments. The loins were sliced into 15 chops of $2 \mathrm{~cm}$ thickness.

\subsection{Consumer Study}

Two different consumer studies were performed: a central location test (CLT) of the appearance of the chops and a home-use test (HUT) of the three selected marinades to assess the liking after barbecuing.

The CLT was carried out in a canteen setting in Taastrup, a suburb of Copenhagen, the capital of Denmark. A total of 109 consumers participated (aged between 20 and 60 years, $61 \%$ male and $39 \%$ female). The consumers evaluated ten samples: the five marinades either as pre-marinated chops or presented next to the chops in a small bag (see Figure 1). The test was performed using a holistic by DMRI ${ }^{\mathrm{TM}}$ approach (Jakobsen et al., 2014), in which the consumers evaluated the extent to which the following attributes were suitable for the product, on a $15 \mathrm{~cm}$ unstructured line scale anchored 1 $\mathrm{cm}$ from each end ranging from "not at all" (0) to "very much" (15): Familiar, Appetizing, Boring, Natural, Strange, Exciting, Sticky and Buying Intention. The order of the attributes was randomised between consumers except Buying Intention, which was always the last attribute. Samples were presented to the consumers in a randomised Latin square design.

Seventy-six families, recruited from the area around Copenhagen, participated in the HUT. Up to four persons per family could evaluate the samples, but from most families 
Table 1. Ingredients in the five marinades given as weight percent.

\begin{tabular}{|c|c|c|c|c|c|}
\hline & Acerola & Dijon & Oregano & Sumac & Barbecue \\
\hline Water & $\mathrm{E}^{1} \_52.7$ & & & & 41.1 \\
\hline Oil & E_20 & 22.2 & 76.1 & 70.4 & \\
\hline Dijon mustard & & 30.9 & & & 1.2 \\
\hline Acerola, freeze dried & 6.0 & 0.6 & & 2.5 & 2.9 \\
\hline Oregano, dried & & 5.6 & 4.1 & & \\
\hline Sumac & & 7.1 & & 7.0 & \\
\hline Sugar, brown & & 12.3 & & & 5.2 \\
\hline Ginger purée & 14.0 & & & & \\
\hline Garlic purée & & & 7.4 & & 2.1 \\
\hline Coriander seeds & & & & 7.0 & \\
\hline Cumin & & & & 7.0 & \\
\hline Chili powder & & & & 1.1 & \\
\hline Spice blend ${ }^{2}$ & & & & & 9.3 \\
\hline Thyme, dried & & & 1.7 & & \\
\hline Onion powder & & & 1.1 & & \\
\hline Pepper, grounded & & 0.6 & & & \\
\hline Tomato concentrate & & & & & 28.9 \\
\hline Soy sauce & & 18.5 & & & \\
\hline Worchester sauce & & & & & 7.2 \\
\hline Apple cider vinegar & & 2.2 & 1.7 & & 2.1 \\
\hline Salt & E_4.0 & & 7.9 & 5.0 & \\
\hline Maizena & E_2.0 & & & & \\
\hline Sodium caseinate & E_1.0 & & & & \\
\hline Guargum & E_0.2 & & & & \\
\hline Xanthan & E_0.1 & & & & \\
\hline Total & 100.0 & 100.0 & 100.0 & 100.0 & 100.0 \\
\hline
\end{tabular}

two persons participated. A total of 176 consumers aged between 20 and 60 participated (95 males and 81 females). On a Friday, the consumers were given three packages of chops and the three marinades: acerola, Dijon and oregano, packed in small bags. The consumers were instructed to barbecue the chops at home on the same day during the weekend in the way they would normally do so. On a line scale $(11.4 \mathrm{~cm})$ ranging from "very bad" to "very good" anchored $1 \mathrm{~cm}$ from each end, the consumers assessed liking of the appearance and odour of the barbecued chop, followed by how much they liked the chop when eaten and finally whether they could imagine buying a chop with this marinade another time. The order of the chops was not controlled, but, since the consumers had to fill in the number of the marinades themselves, a random order between families was expected.

Each family member was asked to complete a short questionnaire including age in 


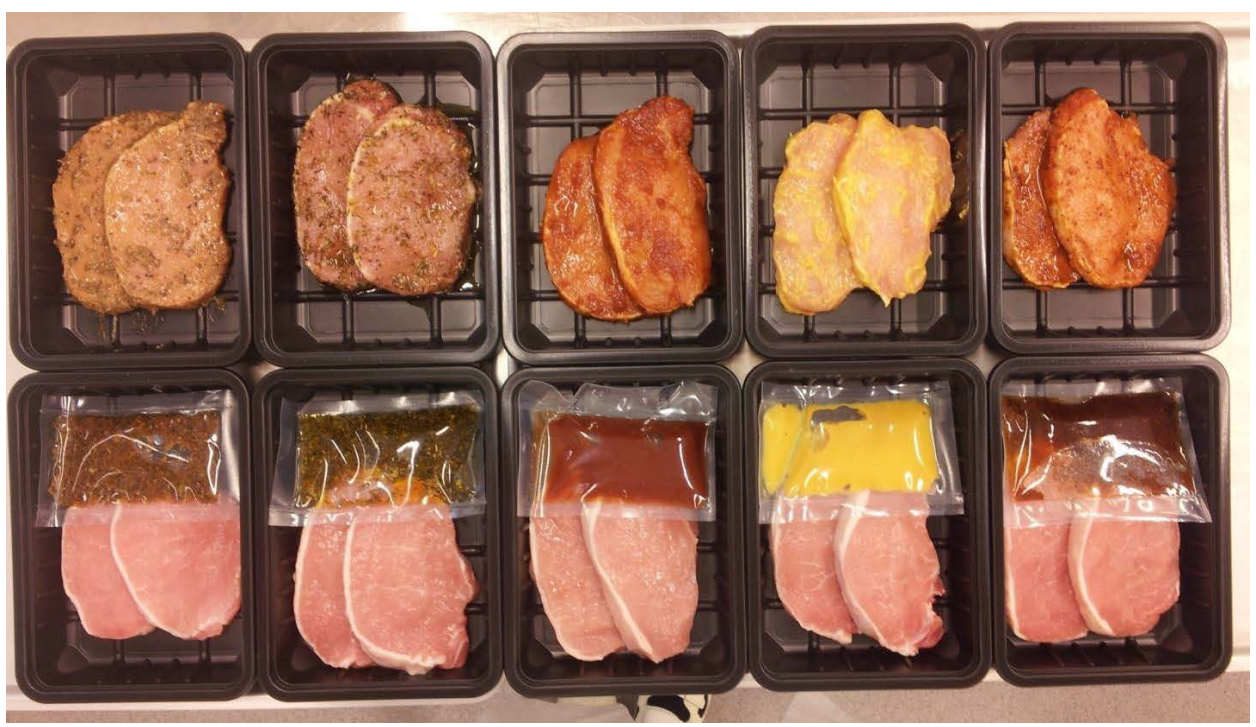

Figure 1. Samples evaluated by the consumers in the CLT. The marinades are from the left: dijon, oregano, barbecue, acerola and sumac.

10-year intervals, gender, how often they had barbecued chops in the barbecue season (every day, every week, every month, more seldom) and how often they ate marinated meat (every week, every month, more seldom).

On the Monday, the consumers returned the questionnaires together with one barbecued chop for each of the three types of marinade.

\subsection{Controlled Cooking}

To investigate the effect of the marinades on reduction of the development of HCAs, controlled barbecue cooking was carried out indoor at Grilleriet (www.grilleriet.dk) with a controlled room temperature $\left(20^{\circ} \mathrm{C}\right)$ and a constant airflow and humidity. A Weber One-touch ${ }^{\oplus}$ premium barbecue and coconut charcoal (www.kokosbriketter, Videbæk, Denmark) were used. Both direct heat using a distance of $10 \mathrm{~cm}$ from the heat (open barbecue) and indirect heat after initially one minute of direct heat, with a distance of $1 \mathrm{~cm}$ from the heat on each side (closed barbecue), were used. When direct heat was used, the chops were turned every two minutes, and when indirect heat in the closed barbecue was used, the chops were turned every third minute to avoid having to open the lid too often. The temperature of the barbecue using direct heat was approximately $270^{\circ} \mathrm{C}$, measured with an infrared thermometer (BUHL \& BØNSØE A/S, Virum, Denmark), while the temperature of the barbecue when using indirect heat was between $240^{\circ} \mathrm{C}$ and $290^{\circ} \mathrm{C}$, measured with the barbecue's built-in thermometer. Six chops with each marinade were grilled simultaneously on the same barbecue. Half of them were removed from the heat when they had reached a core temperature of $65^{\circ} \mathrm{C}$, while the remaining three were grilled until they had reached a core temperature of $80^{\circ} \mathrm{C}$. This was repeated twice, giving a total of six chops for each treatment (barbecue type and temperature). In addition to the three marinades, pork chops marinated in rapeseed oil and pork chops without any marinade (blank) were also grilled, giving a 
total of five different types (three marinades, rapeseed oil, blank), two barbecue types, two core temperatures and six replicates. The 30 treatments were arranged in a Latin square design on pairs of two loins.

\subsection{Estimation of Core Temperature by Multispectral Imaging}

Multispectral imaging (Videometer A/S, Hørsholm, Denmark) was used to estimate the core temperature. Based on the average surface spectra of the chops from the controlled cooking (open barbecue), three separate models were predicted by partial least squares regression (Unscrambler X10.3, Camo software A/S, Oslo, Norway) - one for each marinade. The core temperature of the HUT grilled pork chops was estimated from these models.

\subsection{Analysis of Heterocyclic Aromatic Amines}

The HCAs were extracted from the meat crust using hollow-fibre (HF) extraction followed by an LC-MS/MS analysis [14]. In brief, prepared HF membranes were filled with $0.1 \mathrm{M}$ sulfuric acid as an acidic acceptor solution and then immersed into 1-octanol to fill the fibre pores with the organic solvent.

Blended crust was homogenized in $0.05 \mathrm{M} \mathrm{NaOH}$, and spiked with internal standards (harman-d3, norharman-d7, PhIP-d3), $(100 \mu \mathrm{l}, 2 \mathrm{mg} / \mathrm{l})$. After mixing the homogenate for $1 \mathrm{~h}$, followed by a centrifugation, $2 \mathrm{~mL}$ of the supernatant was transferred for extraction using the HF device. The HF was immersed into the sample and the extraction was carried out for $90 \mathrm{~min}$. The sealed end of the HF was cut off and the acceptor phase inside the fibre lumen was transferred to a vial. The sample amount was adjusted to $0.100 \mathrm{~g}$ with Milli-Q water.

The chromatographic separations were performed with the following modifications: using an ACQuity UPLC BEH C18 $(2.1 \times 50 \mathrm{~mm} 1.7 \mu \mathrm{m})$ column at $40^{\circ} \mathrm{C}$ (Waters Corporation, Milford, Mass., USA) and a Krud Katcher UHPLC in-line filter (0.5 $\mu \mathrm{m}$ depth filter x0.004 in ID, Phenomenex, Torrace, CA, USA) on a uHPLCN exera X2 system (Shimadzu, Kyoto, Japan). Separation was achieved with a binary mobile phase at a flow rate of $0.5 \mathrm{~mL} / \mathrm{min}$. Solvent A was acetonitrile, and solvent B was $10 \mathrm{mM}$ ammonium formiate at $\mathrm{pH}$ 3.0. The gradient elution programme was: $0-0.2 \mathrm{~min}, 95 \% \mathrm{~A}$, $0.2-6.010 \%$ A, $6.1-9.0 \mathrm{~min} 95 \% \mathrm{~A}$, return to original condition. The injection volume was $5 \mu \mathrm{L}$. The analysis used a hybrid triple quadrupole $(\mathrm{QqQ}) /$ linear ion trap mass spectrometer from AB Sciex (QTRAP ${ }^{\circledast} 6500$, AB SCIEX, Concord, ON, Canada).

\subsection{Statistics}

The data from the CLT appearance test were analysed using Panel check (version 1.4.0, Nofima, Norway). A PCA analysis was performed using unstandardised data, first on all data followed by the subset of the chops presented with the marinade in a bag.

Liking data from the HUT were analysed using a mixed model analysis of variance with the marinade as fixed effect and the family as random effect (Proc mixed, SAS version 9.4, Cary NC, USA). 
The logarithmic content of HCAs in the pork chops after controlled cooking was analysed using an analysis of variance with marinade, temperature, grill method and the interaction between these as fixed effects (Proc mixed, SAS version 9.4, Cary NC, USA). The post-hoc comparison was performed using Bonferroni adjustment for multiple comparisons.

\section{Results}

\subsection{Development of Marinades}

In a preliminary study, the antioxidative of several herbs, berries and other active ingredients was assessed using two assays: oxygen consumption and DPPH. This was compared with literature data on ORAC values. On this basis, oregano, sumac and acerola was chosen for the further experiment. In the development of the marinades, other ingredients were added to get the best gastronomic quality. Some of these ingredients are also known to have antioxidative properties. A list can be seen in Table 2.

\subsection{Consumer Tests}

The main difference between the samples in the CLT of appearance was whether they were pre-marinated or packed with the marinade in a bag placed next to them (Figure 2 , left plot). This accounted for $93 \%$ of the variation in the data (PC1). The pre-marinated samples were rated as boring, strange and sticky, while the chops with the marinade in the bag were rated as exciting, appetizing, natural, familiar and with a higher purchase intention score. It was therefore decided to continue the study with the marinade in bags instead of pre-marinated samples.

A closer examination of the samples with the marinades in the bag (right plot) showed that especially the acerola marinade was perceived as being strange and sticky, while especially oregano and Dijon were perceived as being appetizing, exciting, familiar and natural. Barbecue marinade was more sticky, familiar and natural compared

Table 2. Antioxidative properties of used ingredients in the marinades (result from pre-study and literature data).

\begin{tabular}{cccc}
\hline & Oxygen consumption ${ }^{1} \mu \mathrm{mol} \mathrm{TE} / 100 \mathrm{~g}^{2}$ & $\mathrm{DPPH}^{1}, \%^{3}$ & ORAC $\mu \mathrm{mol} \mathrm{TE} / 100 \mathrm{~g}^{\circ}$ \\
\hline Oregano, dried & 6.2 & 12.0 & $200,129^{4}$ \\
Sumac, bran & 3.9 & 11.5 & $312,400^{4}$ \\
Acerola & 59.0 & 8.8 & $70,000^{5}$ \\
Garlic, raw & 1.7 & 7.1 & $5346^{4}$ \\
Ginger & - & - & $28,811^{4}$ \\
Thyme & 2.4 & 11.2 & $157,380^{4}$ \\
Chilli powder & 2.9 & 13.2 & $23,636^{4}$ \\
Onion & - & - & $863^{5}$
\end{tabular}

${ }^{1}$ from a prestudy. ${ }^{2} \mu \mathrm{mol} \mathrm{TE} / 100 \mathrm{~g}$ (micromol Trolox Equivalent per 100 grams). ${ }^{3}$ Scavenging activity in $5 \mathrm{~mL}$ $\mathrm{DM} / \mathrm{mL} .{ }^{4}$ from http://modernsurvivalblog.com/health/high-orac-value-antioxidant-foods-top-100/. ${ }^{5}$ from http://superfoodly.com/superfoodly-orac-values.pdf. 

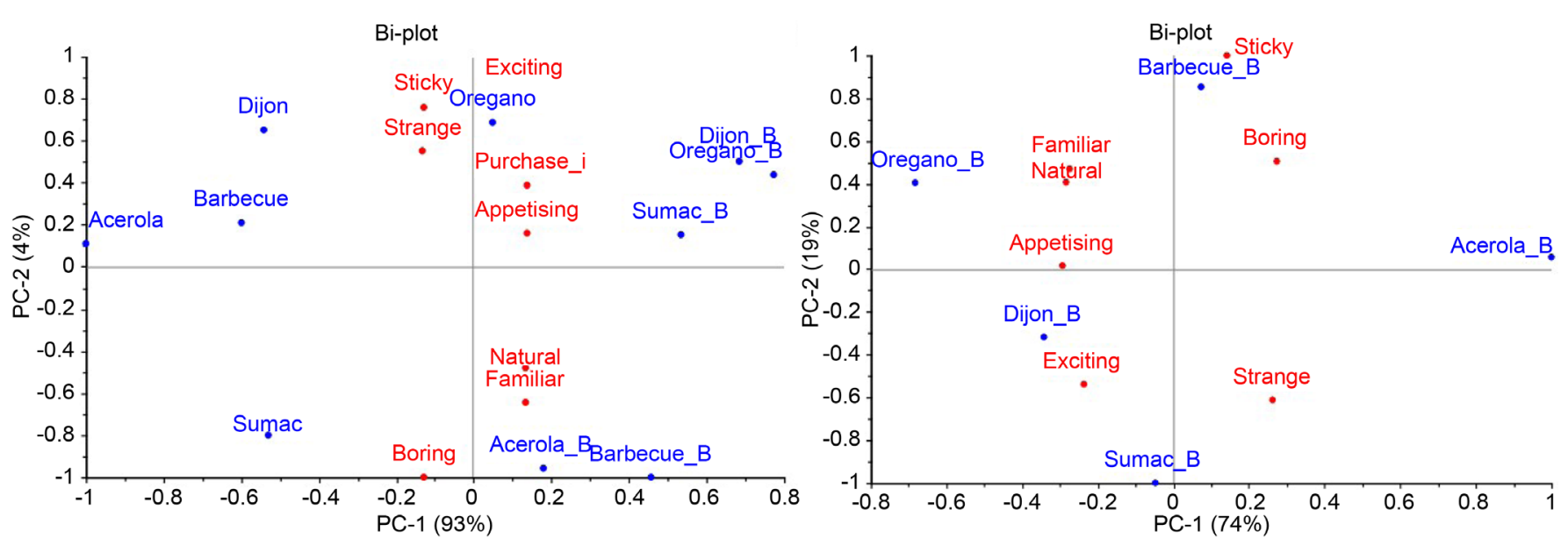

Figure 2. Visual consumer assessment $(n=109)$ of 10 different packages of pork chops (see Figure 1$)$ either pre-marinated or with the marinade presented in a plastic bag, marked_B after the marinade name. In the left plot, all samples are included, whereas only the samples with the marinade in the bag are included in the right plot.

with sumac, which was perceived as being strange, but also exciting. Based on this, the oregano and Dijon marinades were chosen for the HUT and controlled cooking. However, since acerola has strong antioxidant properties, and since a closer examination of the data showed that a small segment of the consumers actually liked it (data not shown), this marinade was selected as the third in the HUT and controlled cooking.

In the HUT, the consumers assessed liking after barbecuing at home. In general, the consumers liked all three types of marinades, with all of them getting an average score above the middle of the scale (Table 3). However, for all attributes, the liking of the acerola marinade was lower than for the oregano and Dijon marinades, which were equally liked. In particular, the question "would you eat it again?" got low ratings for the acerola marinade.

The surface colour of the chops cooked by the consumers was measured using Videometer Lab and related to the surface colour of the chops from the controlled cooking in order to estimate the core temperature (Figure 3 ).

The meat was estimated to be cooked to below $65^{\circ} \mathrm{C}$ by $42 \%$ of the consumers, between $65^{\circ} \mathrm{C}$ and $70^{\circ} \mathrm{C}$ by $24 \%$ and between $70^{\circ} \mathrm{C}$ and $80^{\circ} \mathrm{C}$ by $34 \%$. The methodology of comparing the cooked surface of the consumer chops with the cooked surface of the chops from the controlled cooking is somewhat imprecise. Nevertheless, it was shown that in general only relatively few consumers $(14 \%)$ cooked the chops to above $75^{\circ} \mathrm{C}$.

\subsection{Heterocyclic Aromatic Amines}

Three heterocyclic aromatic amines with mutagenic properties, MeIQx, DiMeIQx and PhiP, were analysed (Table 3(b)). Of these, PhiP was the most abundant. A three-way interaction between marinade, core temperature and cooking method existed for DiMeIQx and PhiP $(\mathrm{P}<0.001)$ but not for MeIQx $(\mathrm{P}=0.176)$, which had a two-way interaction between marinade and cooking method instead $(\mathrm{P}<0.001)$. With indirect cooking, all of the marinades reduced the content of DiMeIQx at both temperatures, 
Table 3. (a) Average liking of marinated chops barbecued at home ( $\mathrm{n}=176)$ assessed on a continuous line scale $(11.4 \mathrm{~cm})$ ranging from "not at all" to "very much". Different letters in each row indicate significant differences $(\mathrm{P} \leq 0.05)$. (b) Average content of MeIQx, DiMeIQx, PhiP, Harman and Norharman (ng/g) in pork chops with and without marinade after cooking over indirect or direct heat on a charcoal barbecue to a core temperature [T] of $65^{\circ} \mathrm{C}$ and $80^{\circ} \mathrm{C}(\mathrm{n}=6)$. The standard deviation is given in brackets. Treatments with different letters were significantly different in the analysis $(\mathrm{P}<0.05)$.

(a)

\begin{tabular}{ccccc}
\hline How much do you like... & Acerola & Dijon & Oregano & p-value \\
\hline the appearance of the grilled chop? & $7.1^{\mathrm{b}} \pm 2.3$ & $8.1^{\mathrm{a}} \pm 2.1$ & $8.2^{\mathrm{a}} \pm 2.2$ & $<0.001$ \\
the odour of the grilled chop? & $6.5^{\mathrm{b}} \pm 2.3$ & $7.9^{\mathrm{a}} \pm 2.1$ & $8.0^{\mathrm{a}} \pm 2.2$ & $<0.001$ \\
the chop when you eat it? & $6.5^{\mathrm{b}} \pm 2.4$ & $7.9^{\mathrm{a}} \pm 2.3$ & $8.0^{\mathrm{a}} \pm 2.4$ & $<0.001$ \\
Would you eat it again? & $5.7^{\mathrm{b}} \pm 3.0$ & $7.6^{\mathrm{a}} \pm 2.9$ & $8.0^{\mathrm{a}} \pm 3.0$ & $<0.001$ \\
\hline
\end{tabular}

(b)

\begin{tabular}{|c|c|c|c|c|c|c|}
\hline MeIQx & $\mathrm{T}$ & Acerola & Dijon & Oregano & Rapeseed Oil & Blank \\
\hline \multirow{2}{*}{ Indirect } & 65 & $0.08^{\mathrm{ab}}(0.10)$ & $0.14^{\mathrm{a}}(0.10)$ & $0.02^{\mathrm{b}}(0.02)$ & $0.11^{\mathrm{ab}}(0.10)$ & $0.29^{\mathrm{a}}(0.14)$ \\
\hline & 80 & $0.13^{\mathrm{ab}}(0.06)$ & $0.10^{\mathrm{ab}}(0.03)$ & $0.06^{\mathrm{b}}(0.07)$ & $0.29^{\mathrm{a}}(0.06)$ & $0.65^{\mathrm{a}}(0.25)$ \\
\hline \multirow[t]{2}{*}{ Direct } & 65 & $0.44^{\mathrm{a}}(0.08)$ & $0.32^{\mathrm{a}}(0.13)$ & $0.47^{\mathrm{a}}(0.20)$ & $0.51^{\mathrm{a}}(0.20)$ & $0.53^{\mathrm{a}}(0.24)$ \\
\hline & 80 & $0.73^{\mathrm{a}}(0.47)$ & $0.95^{\mathrm{a}}(0.31)$ & $1.03^{\mathrm{a}}(0.74)$ & $0.60^{\mathrm{a}}(0.08)$ & $1.11^{\mathrm{a}}(0.40)$ \\
\hline \multicolumn{2}{|c|}{ DiMeIQx } & Acerola & Dijon & Oregano & Rapeseed Oil & Blank \\
\hline \multirow[t]{2}{*}{ Indirect } & 65 & $0.00^{\mathrm{cl}}$ & $0.03^{\mathrm{b}}(0.04)$ & $0.00^{\mathrm{cl}}$ & $0.09^{\mathrm{ab}}(0.07)$ & $0.09^{\mathrm{a}}(0.09)$ \\
\hline & 80 & $0.09^{\mathrm{b}}(0.04)$ & $0.00^{\mathrm{cl}}$ & $0.02^{c}(0.03)$ & $0.11^{\mathrm{ab}}(0.03)$ & $1.55^{\mathrm{a}}(2.28)$ \\
\hline \multirow[t]{2}{*}{ Direct } & 65 & $0.06^{\mathrm{a}}(0.07)$ & $0.05^{\mathrm{a}}(0.07)$ & $0.11^{\mathrm{a}}(0.08)$ & $0.27^{\mathrm{a}}(0.10)$ & $0.19^{\mathrm{a}}(0.07)$ \\
\hline & 80 & $0.49^{\mathrm{a}}(0.49)$ & $0.13^{\mathrm{a}}(0.03)$ & $0.28^{\mathrm{a}}(0.18)$ & $0.13^{\mathrm{a}}(0.04)$ & $1.54^{\mathrm{a}}(1.61)$ \\
\hline \multicolumn{2}{|l|}{ PhiP } & Acerola & Dijon & Oregano & Rapeseed Oil & Blank \\
\hline \multirow[t]{2}{*}{ Indirect } & 65 & $0.25^{\mathrm{b}}(0.15)$ & $0.20^{\mathrm{b}}(0.11)$ & $0.23^{\mathrm{b}}(0.19)$ & $2.17^{\mathrm{a}}(0.10)$ & $4.50^{\mathrm{a}}(1.02)$ \\
\hline & 80 & $0.73^{b c}(0.23)$ & $0.04^{\mathrm{d}}(0.04)$ & $0.23^{c}(0.16)$ & $1.57^{\mathrm{ab}}(0.06)$ & $5.22^{\mathrm{a}}(1.57)$ \\
\hline \multirow[t]{2}{*}{ Direct } & 65 & $0.66^{\mathrm{b}}(0.27)$ & $0.42^{\mathrm{b}}(0.26)$ & $1.37^{\mathrm{ab}}(0.89)$ & $3.69^{\mathrm{a}}(0.20)$ & $5.43^{\mathrm{a}}(2.69)$ \\
\hline & 80 & $3.11^{\mathrm{b}}(5.36)$ & $0.72^{\mathrm{b}}(0.19)$ & $1.52^{\mathrm{b}}(1.08)$ & $3.23^{\mathrm{ab}}(0.08)$ & $11.35^{\mathrm{a}}(3.41)$ \\
\hline \multicolumn{2}{|c|}{ Harman } & Acerola & Dijon & Oregano & Rapeseed Oil & Blank \\
\hline \multirow[t]{2}{*}{ Indirect } & 65 & $1.92^{\mathrm{b}}(0.43)$ & $32.01^{\mathrm{a}}(8.67)$ & $2.47^{\mathrm{b}}(0.20)$ & $2.97^{\mathrm{b}}(1.11)$ & $2.70^{\mathrm{b}}(0.92)$ \\
\hline & 80 & $4.43^{\mathrm{b}}(0.66)$ & $27.57^{\mathrm{a}}(5.47)$ & $2.43^{\mathrm{b}}(0.40)$ & $2.34^{\mathrm{b}}(0.41)$ & $3.35^{\mathrm{b}}(1.39)$ \\
\hline \multirow[t]{2}{*}{ Direct } & 65 & $2.74^{\mathrm{b}}(0.88)$ & $49.58^{\mathrm{a}}(15.21)$ & $4.30^{\mathrm{b}}(2.73)$ & $0.98^{c}(0.20)$ & $0.93^{c}(0.48)$ \\
\hline & 80 & $3.02^{\mathrm{b}}(1.16)$ & $66.57^{\mathrm{a}}(14.77)$ & $4.59^{\mathrm{b}}(2.55)$ & $1.09^{\mathrm{b}}(0.22)$ & $3.55^{\mathrm{b}}(1.66)$ \\
\hline \multicolumn{2}{|c|}{ Norharman } & Acerola & Dijon & Oregano & Rapeseed Oil & Blank \\
\hline \multirow[t]{2}{*}{ Indirect } & 65 & $4.02^{\mathrm{b}}(1.26)$ & $11.39^{\mathrm{a}}(2.83)$ & $3.35^{\mathrm{b}}(0.37)$ & $5.76^{\mathrm{ab}}(2.49)$ & $3.44^{\mathrm{b}}(1.14)$ \\
\hline & 80 & $9.42^{\mathrm{ab}}(1.63)$ & $10.67^{\mathrm{a}}(2.49)$ & $4.52^{\mathrm{b}}(0.70)$ & $6.60^{\mathrm{ab}}(1.61)$ & $8.46^{\mathrm{ab}}(8.16)$ \\
\hline \multirow[t]{2}{*}{ Direct } & 65 & $2.41^{\mathrm{b}}(0.46)$ & $10.38^{\mathrm{a}}(3.23)$ & $3.52^{\mathrm{b}}(1.90)$ & $1.97^{\mathrm{b}}(0.19)$ & $1.51^{\mathrm{b}}(0.43)$ \\
\hline & 80 & $3.17^{\mathrm{c}}(1.76)$ & $11.62^{\mathrm{a}}(1.71)$ & $3.96^{\mathrm{bc}}(1.51)$ & $2.43^{\mathrm{c}}(0.58)$ & $5.66^{\mathrm{b}}(2.50)$ \\
\hline
\end{tabular}

${ }^{1}$ Values $<$ LOQ. 


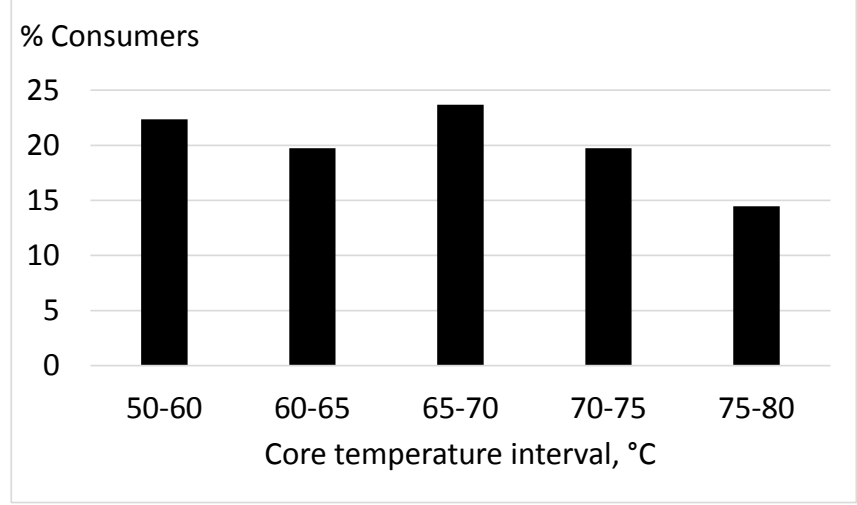

Figure 3. Percentage of consumers who cooked the pork chops to different core temperatures. The core temperature was estimated based on the surface colour of the chops from the controlled cooking using direct heat on each of the three marinades. The average of the estimated core temperatures of the three chops per consumer was calculated and further divided into temperature intervals.

while the reduction was only significant for MeIQx in the oregano marinade, in which the formation of HCAs in general was almost totally inhibited. No effect was seen when cooking over direct heat for DiMeIQx and MeIQx. In contrast, PhiP was inhibited independently of the cooking method and temperature and was only insignificant for the oregano marinade when cooking over direct heat to a core temperature of $65^{\circ} \mathrm{C}$.

Harman and Norharman have comutagenic activity, meaning that they themselves have no mutagenic effects but can increase the mutagenicity of other HCAs (Jägerstad, Skog, Arvidsson, \& Solyakov, 1998). Unfortunately, a consistent and very high concentration of, in particular, Harman, but also Norharman, was seen after marinating with the Dijon marinade. The concentration was much higher than in the control sample. No clear reducing effect of the other marinades was seen on Harman and Norharman compared with the blank sample.

Cold pressed rapeseed oil used for the marinades has an antioxidant effect on its own, and it was therefore of interest also to investigate the effect of the pure oil. No significant reduction of pure rapeseed oil was seen for any of the investigated HCAs except Norharman cooked over direct heat to $80^{\circ} \mathrm{C}$. However, a numerical decrease was seen, indicating that the oil might have some properties that inhibit the formation of HCAs.

\section{Discussion}

\subsection{Consumer Test}

Barbecuing is one of the cooking methods that results in the highest content of HCAs [26], and previous research has shown that approximately half of the consumers in a home use study used marinades before barbecuing pork chops [14]. This provides an opportunity to develop tailor-made marinades that inhibit the formation of HCAs based on the knowledge about the antioxidant activities of different herbs and berries. All three marinades consisted of several ingredients, as the aim was to investigate the 
effect of a complex marinade. Other ingredients than acerola, sumac and oregano has therefore contributed to the antioxidative effect of the marinade. However, the aim was not especially to focus on the effect of these three ingredients, but to demonstrate the possibility of combining gastronomy and chemical research to develop effective marinades, including ingredients that initially have a high antioxidant effect. Success will depend on the sensory quality of the marinades being high as well. The sensory quality of the marinated meat has only been included in a few studies, in which more or less trained panels were used [8] [27] [28]. In this study, consumer tests were used to assess the sensory quality. In comparison, other studies have focused on marinades that did not alter the sensory quality [28]. In the CLT, the consumers clearly appreciated the marinade being presented in a bag together with the pork chops instead of pre-marinated chops.

Based on the test of the appearance, three marinades were chosen for further studyDijon and oregano, which were clearly appreciated, and acerola, due to its promising antioxidant activity, even though only a few of the consumers liked the appearance. This lower liking was also found during the HUT, with the acerola marinade getting lower scores for all attributes, especially the question "would you eat it again?", compared with the Dijon and oregano marinades.

When the controlled grilled samples were used to estimate the core temperature of the consumer samples, it was seen that only approximately one third of the consumers cooked the meat to above $70^{\circ} \mathrm{C}$. This is in contrast to a previous study in Denmark, in which more than half of the estimated core temperatures in consumer-cooked pork chops were $75^{\circ} \mathrm{C}$ or more [14]. This difference might be due to the fact that the relationship between well-done meat and cancer has received media coverage in Denmark since the first study. This is important, since longer cooking times increase the concentration of, in particular, PhiP and MeIQx, but also diMeIQx [1], which was also confirmed in this study, where the content of all HCAs was higher in the chops cooked to $80^{\circ} \mathrm{C}$ compared with $65^{\circ} \mathrm{C}$ in the control samples. Shorter cooking times resulting in a lower degree of doneness are therefore recommended.

\subsection{Heterocyclic Aromatic Amines}

In the controlled barbecuing, coconut charcoal was used because they are said to give a higher and more stable temperature (Grilleriet ${ }^{\oplus}$, personal communication), which is crucial to keeping the conditions as controlled as possible during the cooking process. It has been shown that the concentration of PhiP is lower in meat cooked on this type of charcoal compared with wood charcoal [29]. Other types of charcoal might therefore have resulted in a higher formation of HCAs and thereby also a greater potential of reducing PhiP.

PhiP was the most abundant HCA, which confirms several other studies [1] [12] [30] [31], although MeIQx, DiMeIQx, Harman and Norharman were also present in detectable concentrations. The reducing effect of the three marinades was not consistent for all five HCAs analysed in this study. For MeIQx and DiMeIQx, a reduction was 
generally seen for all marinades when barbecuing on indirect heat, whereas no effect was seen when barbecuing on direct heat. The concentration of PhiP was also reduced by the marinades for both types of barbecue at both temperatures. In contrast, the concentration of Harman, and to a lesser extent Norharman, was increased considerably by the Dijon marinade, even though the antioxidant potential of this marinade was similar to that of the other marinades. The Dijon marinade contained oregano, sumac and acerola as well as Dijon mustard, brown sugar and soy sauce. The increasing effect of Dijon marinade on Harman and Norharman was not seen in the other two marinades, which also contained oregano and acerola, and it must therefore have been caused by some of the other ingredients. Previously, it has been indicated, that sugar as well as soy sauce might increase the formation of MeIQx, 4, 8DiMeIQx and PhiP [32]. This was not seen in this study, but it cannot be rejected, that the sugar and soy sauce are responsible for the increase in Harman and Norharman. The Dijon marinade cannot be recommended due to its high concentrations of Harman and Norharman, even though the content of the other mutagenic HCAs is very low.

The acerola marinade was neither well-liked nor as effective as the oregano marinade in reducing the HCAs, especially at $65^{\circ} \mathrm{C}$, even though acerola is known to be an effective antioxidant [21]. The reason for this lower efficiency is not known, although it could be due to the different compositions of the active groups in oregano, which are a varity of polyphenols, flavonoids and different compounds in the essential oil such as carvacrol, thymol, $\gamma$-terpinene and linalool [17] [18] and acerola, which are a combination of ascorbic acid [22] and phenolic compounds [23]. Another explanation could be the other ingrediens in the oregano marinade as especially garlic and onions are both known to have a high antioxidative capacity (Table 2) and a high efficiency in reducing the formation of HCAs [33], but also thyme, which is present in a lower concentration (Table 1) can reduce the formation of HCA's though to a lesser extend than oregano [34]. This leaves the oregano marinade as the most appreciated and most effective marinade for healthy barbecuing.

\section{Conclusion}

This study clearly demonstrates that it is possible to tailor-make marinades that are effective in inhibiting the formation of heterocylic aromatic amines based on knowledge about the antioxidant capacity of herbs and berries and shows that the herbs and berries were effective as ingredients in a complex marinade. However, it was also shown that knowledge about the antioxidant capacity was in itself insufficient to predict the effectiveness of the marinade, since the content of Harman and Norharman was surprisingly high in the Dijon marinade. Using consumer studies is an effective and powerful way to investigate liking of marinades.

\section{Acknowledgements}

This study was funded by the Pig Levy fund, to whom we are very grateful. A special thanks to master's student Lone Green Ensig, who developed the marinades and per- 
formed the consumer studies, and to Jane Skou Olsen, Tine Frogne and Pia Krall Fauschou, who performed the chemical analysis of the HCAs. Claus Borggaard is thanked for doing the data analysis on the multispectral imaging data.

\section{References}

[1] Yan, Z., et al. (2013) Formation and Mitigation of Heterocyclic Aromatic Amines in Fried Pork. Food Additives \& Contaminants: Part A, 30, 1501-1507. http://dx.doi.org/10.1080/19440049.2013.809627

[2] Sanz-Alaejos, M. and Afonso, A. (2011) Factors That Affect the Content of Heterocyclic Aromatic Amines in Foods. Comprehensive Reviews in Food Science and Food Safety, 10, 52-108. http://dx.doi.org/10.1111/j.1541-4337.2010.00141.x

[3] Ur Rahman, U., et al. (2014) Production of Heterocyclic Aromatic Amines in Meat: Chemistry, Health Risks and Inhibition. A Review. LWT-Food Science and Technology, 59, 229233. http://dx.doi.org/10.1016/j.lwt.2014.06.005

[4] Hill, M. (2002) Meat, Cancer and Dietary Advice to the Public. European Journal of Clinical Nutrition, 56, S36-S41. http://dx.doi.org/10.1038/sj.ejcn.1601352

[5] Fund, W.C.R. (2007) Food, Nutrition, Physical Activity and Prevention of Cancer: a Global Perspective. American Institute for Cancer Research, Washington DC.

[6] Alaejos, M.S., Pino, V. and Afonso, A.M. (2008) Metabolism and Toxicology of Heterocyclic Aromatic Amines When Consumed in Diet: Influence of the Genetic Suspensibility to Develop Human Cancer. A Review. Food Research International, 41, 327-340. http://dx.doi.org/10.1016/j.foodres.2008.02.001

[7] Kanithaporn, P. and Smith, J. (2010) Inhibition of Heterocyclic Amine Formation in Beef Patties by Ethanolic Extracts of Rosemary. Journal of Food Science, 75, T40-T47. http://dx.doi.org/10.1111/j.1750-3841.2009.01491.x

[8] Viegas, O., et al. (2012) Inhibitory Effect of Antioxidant-Rich Marinades on the Formation of Heterocyclic Aromatic Amines in Pan-Fried Beef. Journal of Agricultural and Food Chemistry, 60, 6235-6240. http://dx.doi.org/10.1021/jf302227b

[9] Natale, D., et al. (2014) Inhibitory Effect of Liposomal Solutions of Grape Seed Extract on the Formation of Heterocyclic Aromatic Amines. Journal of Agricultural and Food Chemistry, 62, 279-287. http://dx.doi.org/10.1021/jf4035332

[10] Viegas, O., Moreira, P. and Ferreira, I. (2015) Influence of Beer Marinades on the Reduction of Carcinogenic Heterocyclic Aromatic Amines in Charcoal-Grilled Pork Meat. Food Additives \& Contaminants: Part A, 32, 315-323.

[11] Kehlet, U., Meinert, L. and Aaslyng, M.D. (2011) The Effects of Addition of Antioxidants, Pan-Frying Temperature and Microwave Heating on Formation of Heterocyclic Aromatic Amines in Pork Products. 57 th International Congress of Meat Science and Technology, Ghent, 7-12 August 2011.

[12] Dong, A., Lee, J. and Shin, H.-S. (2011) Influence of Natural Food Ingredients on the Formation of Heterocyclic Amines in Fried Beef Patties and Chicken Breasts. Food Science and Biotechnology, 20, 359-365. http://dx.doi.org/10.1007/s10068-011-0050-5

[13] Busquets, R., et al. (2006) Effect of Red Wine Marinades on the Formation of Heterocyclic Amines in Fried Chicken Breast. Journal of Agricultural \& Food Chemistry, 54, 8376-8384. http://dx.doi.org/10.1021/jf0616311

[14] Aaslyng, M., et al. (2013) Content of Heterocyclic Amines and Polycyclic Aromatic Hydrocarbons in Pork, Beef and Chicken Barbecued at Home by Danish Consumers. Meat 
Science, 93, 85-91. http://dx.doi.org/10.1016/j.meatsci.2012.08.004

[15] Awney, H. (2011) The Effect of Green Tea and Olive Oil on the Mutagenic Activity of Heterocyclic Amines Extracted from Common Food Consumed in Saudi Arabia. International Journal of Food Sciences and Nutrition, 62, 295-302. http://dx.doi.org/10.3109/09637486.2010.529070

[16] Cheng, K.-W., et al. (2007) Inhibitory Effect of Fruit Extracts on the Formation of Heterocyclic Amines. Journal of Agricultural and Food Chemistry, 55, 10359-10365. http://dx.doi.org/10.1021/jf071820z

[17] Zhang, X.-L., et al. (2014) Phenolic Compounds from Origanum vulgare and Their Antioxidant and Antiviral Activities. Food Chemistry, 152, 300-306.

http://dx.doi.org/10.1016/j.foodchem.2013.11.153

[18] Teixeira, B., et al. (2013) Chemical Composition and Bioactivity of Different Oregano (Origanum vulgare) Extracts and Essential Oil. Journal of the Science of Food and Agriculture, 93, 2707-2714. http://dx.doi.org/10.1002/jsfa.6089

[19] Radha Krishnan, K., et al. (2014) Antimicrobial and Antioxidative Effects of Spice Extracts on the Shelf Life Extension of Raw Chicken Meat. International Journal of Food Microbiology, 171, 32-40. http://dx.doi.org/10.1016/j.ijfoodmicro.2013.11.011

[20] Damasius, J., et al. (2015) Assessment of the Influence of Some Spice Extracts on the Formation of Heterocyclic Amines in Meat. Food Chemistry, 126, 149-156. http://dx.doi.org/10.1016/j.foodchem.2010.10.091

[21] Nobrega, E., et al. (2015) The Impact of Hot Air Drying on the Physical-Chemical Characteristics, Bioactive Compounds and Antioxidant Activity of Acerola (Malphigia emarginata) Residue. Journal of Food Processing and Preservation, 39, 131-141. http://dx.doi.org/10.1111/jfpp.12213

[22] Vendramini, A.L. and Trugo, L.C. (2000) Chemical Composition of Acerola Fruit (Malpighia punicifolia L.) at Three Stages of Maturity. Food Chemistry, 71, 195-198. http://dx.doi.org/10.1016/S0308-8146(00)00152-7

[23] De Rosso, V.V. and Mercandante, A.Z. (2005) Carotenoid Composition of Two Brazilian Genotypes of Acerola (Magpighia punicifolia L.) from Two Harvests. Food Research International, 38, 1073-1077. http://dx.doi.org/10.1016/j.foodres.2005.02.023

[24] Realini, C., et al. (2015) Effects of Acerola Fruit Extract on Sensory and Shelf-Life of Salted Beef Patties from Grinds Differing in Fatty Acid Composition. Meat Science, 99, 18-24. http://dx.doi.org/10.1016/j.meatsci.2014.08.008

[25] Abu-Reidah, I.M., et al. (2015) HPLC-DAD-ESI-MS/MS Screening of Bioactive Components from Rhus coriaria L. (Sumac) Fruits. Food Chemistry, 166, 179-191. http://dx.doi.org/10.1016/j.foodchem.2014.06.011

[26] Skog, K. and Solyakov, A. (2002) Heterocyclic Amines in Poultry Products: A Literature Review. Food and Chemical Toxicology, 40, 1213-1221. http://dx.doi.org/10.1016/S0278-6915(02)00062-5

[27] Szterk, A. and Jesionkowska, K. (2015) Influence of the Cold Storage Time of Raw Beef Meat and Grilling Parameters on Sensory Quality and Content of Heterocyclic Aromatic amines. LWT-Food Science and Technology, 61, 299-308. http://dx.doi.org/10.1016/j.lwt.2014.12.005

[28] Gibis, M. and Weiss, J. (2010) Inhibitory Effect of Marinades with Hibiscus Extract on Formation of Heterocyclic Aromatic Amines and Sensory Quality of Fried Beef Patties. Meat Science, 85, 735-742. http://dx.doi.org/10.1016/j.meatsci.2010.03.034

[29] Viegas, O., et al. (2012) Effect of Charcoal Types and Grilling Conditions on Formation of 
Heterocyclic Aromatic Amines (HAs) and Polycyclic Aromatic Hydrocarbons (PAHs) in Grilled Muscle Foods. Food and Chemical Toxicology, 50, 2128-2134. http://dx.doi.org/10.1016/j.fct.2012.03.051

[30] Sinha, R., et al. (1998) Heterocyclic Amino Content of Pork Products Cooked by Different Methods and to Varying Degrees of Doneness. Food \& Chemical Toxicology, 36, 289-297. http://dx.doi.org/10.1016/S0278-6915(97)00159-2

[31] Smith, J.S., Ameri, F. and Gadgil, P. (2008) Effect of Marinades on the Formation of Heterocyclic Amines in Grilled Beef Steaks. Journal of Food Science, 73, T100-T105. http://dx.doi.org/10.1111/j.1750-3841.2008.00856.x

[32] Lan, C.M. and Chen, B.H. (2002) Effect of Soy Sauce and Sugar on the Formation of Heterocyclic Amines in Marinated Foods. Food and Chemical Toxicilogy, 40, 989-1000. http://dx.doi.org/10.1016/S0278-6915(02)00013-3

[33] Janoszka, B. (2010) Heterocyclic Amines and Azaarenes in Pan-Fried Meat and Its Gravy Fried without Additives and in the Presence of Onion and Garlic. Food Chemistry, 120, 463-473. http://dx.doi.org/10.1016/j.foodchem.2009.10.039

[34] Damašius, J., Venskutonis, P.R., Ferracane, R. and Fogliano, V. (2011) Assessment of the Influence of Some Spice Extracts on the Formation of Heterocyclic Amines in Meat. Food Chemistry, 126, 149-156. http://dx.doi.org/10.1016/j.foodchem.2010.10.091

Submit or recommend next manuscript to SCIRP and we will provide best service for you:

Accepting pre-submission inquiries through Email, Facebook, LinkedIn, Twitter, etc. A wide selection of journals (inclusive of 9 subjects, more than 200 journals)

Providing 24-hour high-quality service

User-friendly online submission system

Fair and swift peer-review system

Efficient typesetting and proofreading procedure

Display of the result of downloads and visits, as well as the number of cited articles Maximum dissemination of your research work

Submit your manuscript at: http://papersubmission.scirp.org/

Or contact fns@scirp.org 